\section{Syringomyelia and Intradural Extramedullary Tuberculoma of the Spinal Cord as a Late Complication of Tuberculous Meningitis}

\author{
Tüberküloz Menenjitin Geç \\ Komplikasyonu Olarak Gelișen IDEM \\ Tüberkülom ve Siringomyeli
}

\begin{abstract}
Intradural extramedullary (IDEM) tuberculomas account for only $1 \%$ of all spinal tuberculomas. Concurrent IDEM tuberculoma and syringomyelia arising as a complication of tuberculous meningitis (TM) is extremely rare and only two cases have been reported to date. There is yet no report in the literature describing syringomyelia presenting as a delayed complication of IDEM tuberculoma. Here we present such a case. A 21 year-old male patient underwent partial decompression for thoracolumbar IDEM tuberculoma as a late complication of tuberculous meningitis. Spinal magnetic resonance imaging (MRI) of the patient suffering from progression of paraparesia six months after the operation revealed a syringomyelia occupying the space from $\mathrm{T} 1$ to $\mathrm{T} 9$, remote from the operation site, and syringo-peritoneal shunt placement was performed.
\end{abstract}

KEYWORDS: Intradural extramedullary tuberculoma, Syringomyelia, Tuberculous meningitis

\section{öz}

İntraduralekstramedüller(IDEM) tüberkülom, tüm spinal kord tüberkülomlarının sadece $\% 1$ 'den sorumludur. IDEM tüberkülomu sonrası siringomiyeli gelişimi son derece nadirdir ve literatürde bugüne dek bu şekilde sadece 2 vaka bildirilmiştir. Literatürde IDEM tüberkülomunun geç komplikasyonu olarak siringomyeli gelişimi bugüne kadar bildirilmemiştir. Burada böylesi bir olguyu sunuyoruz: 21 yaşındaki bir erkek hastaya tüberküloz menenjitin geç bir komplikasyonu olarak ortaya çıan torakololomber İDEM tüberkülomu nedeni ile parsiyel dekompresyon uyguland. Operasyondan 6 ay sonra paraparezisi ilerleyen hastanın yapılan spinal manyetik rezonans görüntülemesinde T1'den T9'a kadar uzanan, operasyon sahasından uzakta siringomiyeli izlenmesi üzerine siringoperitoneal şant yerleştirildi.

ANAHTAR SÖZCÜKLER: İntradural ekstramedüller tüberkülom, Siringomiyeli, Tüberküloz menenjit

\section{Sanser GUL1 \\ Guven CELEBI ${ }^{2}$ \\ Murat KALAYCI ${ }^{3}$ \\ Bektas ACIKGOZ4 \\ 1,3,4 Karaelmas University, School of Medicine, Department of Neurosurgery, Zonguldak, Turkey \\ 2 Karaelmas University, School of Medicine, Infectious Disease and Clinical Microbiology, Zonguldak, Turkey}

Received : 04.09.2009

Accepted : 06.10.2009

Correspondence address: Sanser GUL

Phone : +90 3722612001

Fax : : +90 3722610264

E-mail :drsanser@yahoo.com 


\section{INTRODUCTION}

Spinal tuberculosis may affect the vertebrae as well as non-osseous structures of the spine. Nonosseous spinal cord involvement is an extremely rare manifestation of tuberculosis. In the spine, tuberculomas may arise in an extradural, or intradural-extramedullary (IDEM), or intramedullary location $(5,9)$. IDEM tuberculomas account for only $1 \%$ of all spinal tuberculomas (3) and less than 30 cases have been reported in the literature up to date $(1,2,9,11,12,14,16)$. Most cases develop following an episode of tuberculous meningitis (TM). Furthermore, syringomyelia as a complication of TM has rarely been reported $(7,8,12)$. Concurrent IDEM tuberculoma and syringomyelia as a complication of $\mathrm{TM}$ is even more extremely rare and only two cases have been reported thus far $(8,14)$. This is another report of syringomyelia that occurred six months after partial removal of IDEM tuberculoma in a patient under medical treatment for TM.

\section{CASE REPORT}

A21-year-old malepresented with a3-weekhistory of backache, progressive weakness of the lower extremities and walking disability. Additionally, he had complaints of cough and weight loss for two months. On examination, the patient was cachectic, with spastic paraparesis of only gravity strength and a T10 sensory level. He had a neurogenic bladder (insensitive, hypercompliant bladder) according to urodynamic findings. Spinal MRI revealed an IDEM lesion at the T11-12, L1 level, formal changes at the T10 -T11 disc space and appearance concordant to spondylodiscitis with destruction at the last plaques of both vertebrae (Figure 1,2).

His anamnesis revealed that he had been hospitalized three months ago with complaints of headache, fever, and loss of consciousness, and diagnosed as TM in another institution. Four-drug anti-tuberculous therapy including rifampin (600 $\mathrm{mg} / \mathrm{d}$ ), isoniasid (300 $\mathrm{mg} / \mathrm{d})$, ethambutol (1500 mg/ d) and pyrasinamide $(2000 \mathrm{mg} / \mathrm{d})$ and prednisolone $(1 \mathrm{mg} / \mathrm{kg} / \mathrm{d})$ had been started. Response to this therapy had been good with most of his initial complaints improving and he had been discharged after four weeks. Completion of two months of the four-drug regimen and then a shift to ten months of a two-drug regimen comprising isoniasid and rifampin was planned. However, during this therapy, progressive lower extremity weakness and walking disability had emerged, in the third month.
Operativeintervention was performed in our clinic due to the patient's progressive symptoms. During surgery, the dura was opened after laminectomy and subdural purulent material and granulomatous tissue completely surrounding the spinal cord and adherent to dorsal nerve rootlets were seen (Figure 3). The granulomatous tissue could not be removed completely because of the dense adhesions. A midline decompression and extensive duraplasty were performed using the thoracolumbar fascia. Due to the extensive nature of decompression, an instrumented stabilization was performed with a pedicle screw rod construct.

Polymerase chain reaction (PCR) for mycobacterium tuberculosis and acid-fast bacilli in Ziehl Nielsen stain were positive on the surgical material; however, culture from the sample remained sterile for bacteria, fungi or mycobacterium tuberculosis. Histopathological examination of the surgical material revealed granulomatous inflammation including coagulation necrosis surrounded by epithelioid histiocytes, lymphocytes and multinuclear giant cells. Imaging studies of the

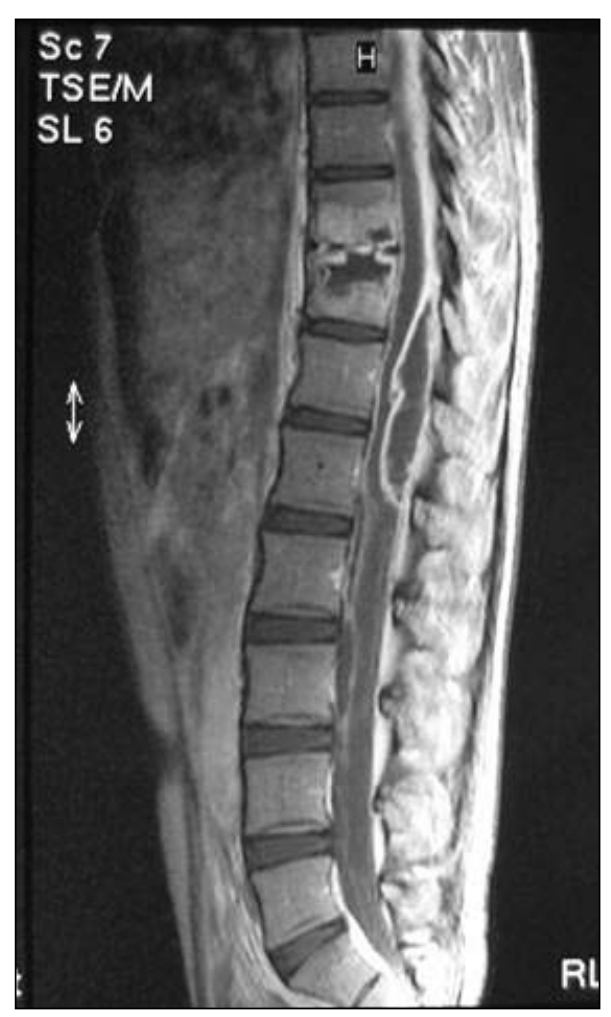

Figure 1: Sagittal, contrast-enhanced T1-weighted turbo-spin echo (TSE) MRI demonstrating an intradural-extramedullary lesion from T12 to L3 with circumferential enhancement and spondylodiscitis at T10-T11 level. 


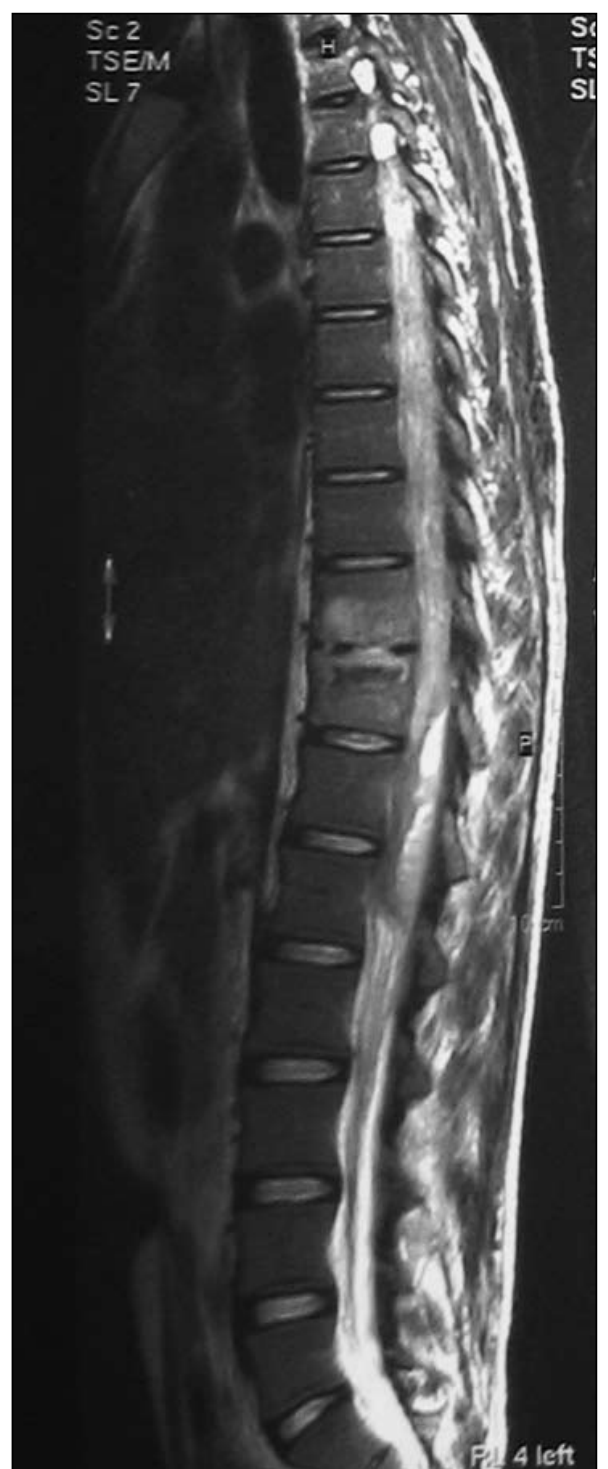

Figure 2: Sagittal T2-weighted MRI image of high thoracic levels prior to first surgery of the patient. There is no sign of any syringomyelia in this image.

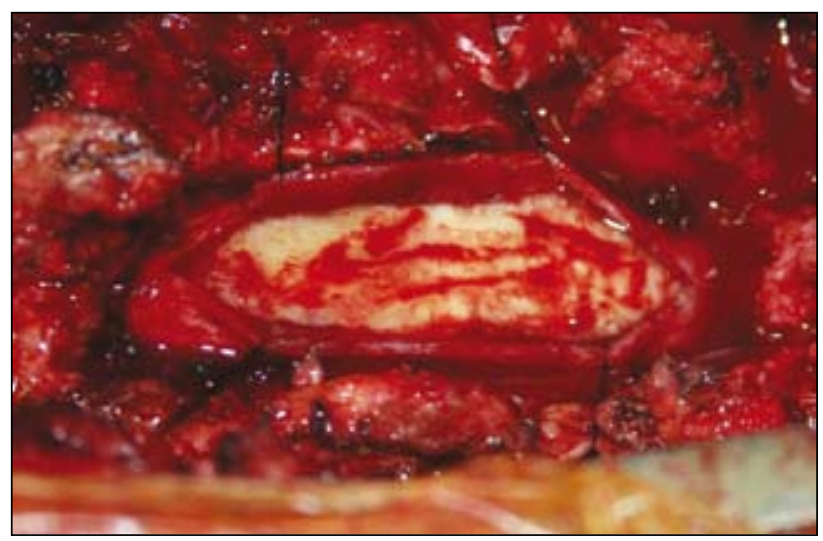

Figure 3: Granulomatous tissue entirely surrounded the spinal cord and was adherent to dorsal nerve rootlets. thorax and abdomen were normal. Acid-fast bacilli (AFB) stain, as well as sputum and urine cultures were all negative for Mycobacterium tuberculosis. Treatment with two-drug anti-tuberculous therapy was continued. The patient was able to walk with crutches in the postoperative first month. However, he suffered from bilateral paraesthesia, weakness in his legs and walking disability in the postoperative sixth month. Spinal MR revealed syringomyelia occupying the space from T1 to T9 (Figure 4). No additional lesion was detected and a syringoperitoneal shunt procedure was performed. The MR image of high thoracic levels prior to the first surgery of the patient is presented in Figure 4. There is no sign of any syringomyelia in this image.

Paraparesia improved in the postoperative first month. The patient has remained stable, uses crutches to walk and had no additional symptoms at the twoyear follow-up.

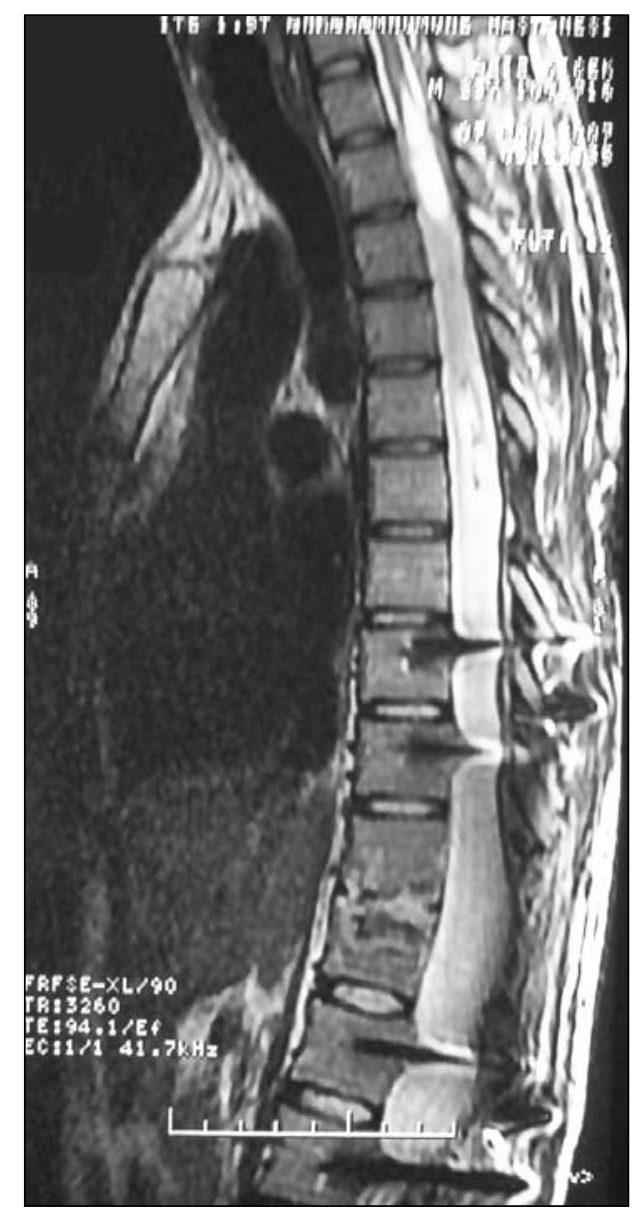

Figure 4: Sagittal T2-weighted MRI at six months revealed a thoracic syringomyelia from T1 to T9 with same signal intensity as the CSF, remote from the original operation site. 


\section{DISCUSSION}

Primary spinal syringomyelia is most commonly associated with spinal trauma and is also encountered as a sequela of intradural inflammatory processes, as a delayed response to surgical procedures, and in association with intra- and extradural neoplasms as well as disc protrusions (1). Compression or at least partial obstruction of the subarachnoid space is postulated to be a factor common to all these conditions. Arachnoid scars or bands appear to be present in patients with a history of trauma and inflammation, as well as in those with a postsurgical syrinx development (3).

Concurrent IDEMtuberculoma and syringomyelia arising as a complication of tuberculous meningitis (TM) is extremely rare and only two cases have been reported to date. There is yet no report in the literature describing syringomyelia presenting as a delayed complication of IDEM tuberculoma.

Muthukumar presented a 27-year-old woman with paraparesis of 2-month duration. She had been treated for TM 8 months earlier. She was found to have an extensive syringomyelia from $\mathrm{C} 2$ to the conus medullaris and an intradural extramedullary tuberculoma at the lower thoracic levels In our case there was no syringomyelia at the time of granuloma formation. Repeat MRI revealed a syringomyelia previously which was unnoticed.

Hui described a 21-year-old immunocompetent woman presented with fever and headache and was started on anti-TB therapy for tuberculous meningitis. Her condition was complicated by hydrocephalus and a ventriculo-peritoneal shunt was inserted. Six months later she developed paraesthesia of both legs followed by a flaccid paraparesis. MRI of the spinal cord demonstrated arachnoiditis, showing diffuse meningeal enhancement of the pia and arachnoid with extramedullary granuloma formation and she was treated medically. One year later she developed another episode of arachnoiditis. Repeat axial nonenhanced T- 1 weighted MR of the spine revealed the formation of a syrinx with a large solid intramedullary tuberculoma at the level of T12. In our case the granuloma formation was intramedullary in contrast to Hui where there was extramedullary granuloma formation as well as intramedullary.

In earlier reports of patients with IDEM tuberculoma, the authors stated that medical treatment alone could not improve the clinical status of the patients with signs of spinal compression; the prognosis was good if the lesion was localized and if the spinal canal could be decompressed by surgery $(4,10,11,13,15)$. Mathuriya reported good results after surgical treatment in four cases (12).

In this study, although IDEM granulomatous inflammatory tissue was not removed completely, the response to surgical and anti-tuberculous medical treatment was fruitful. Screws were placed at the pedicules of the T8-T9 and T12-L1 vertebrae which unaffected by the infection. No intervention was performed to the T10-11 level due to the absence of anterior spinal cord compression.

Our case revealed that radical resection of the granuloma surrounding the spinal cord may not be possible, and in such a situation it may be better to avoid total removal, and thus potential neurological disability. Nevertheless, this may be at the expense of syringomyelia, as was true in this case.

The mechanism of syringomyelia formation due to inflammatory arachnoiditis includes ischemic myelomalacia secondary to inflammatory occlusion of the spinal cord vessels with subsequent syringomyelia formation. Focal scarring causes a block in the CSF circulation, thus forcing the CSF into the central canal of the spinal cord via Virchow Robin spaces. Obstruction of Virchow Robin spaces also occurs; focal cystic dilatations in the cord eventually coalesce to form syringomyelia (9). Syrinx formation is thought to be secondary to either an obliterative endarteritis causing ischemic injury and softening or postinflammatory scarring which leads to spinal block $(3,8)$

Blockage of the spinal subarachnoid CSF pathway produces a relative increase in the pressure inside the spinal cord distal to the blockage point. Thus, in the segment distal to the blockage, the pressure inside the spinal cord becomes relatively larger than that outside. Repetitive formation of this pressure gradient at each CSF pulse leads to leakage of CSF from the central canal, causing interstitial oedema and the formation of a syrinx (14).

Yasemin et al. reported a case with syringomyelia secondary to TM, and the authors concluded that syringomyelia was associated with inadequate treatment of TM due to drug resistance (6). In our case, signs and symptoms of TM improved with 
anti-tuberculous medication, and all cultures for mycobacteria obtained from the tuberculoma of the spine and from many sites of the patient were negative. Therefore, it is inferred that IDEM tuberculoma or syringomyelia was not related with drug resistance in our patient. Muthukumar and Sureshkumar have reported a case with concurrent syringomyelia and IDEM tuberculoma as late complications of TM and the authors have stated that the presence of a dense IDEM tuberculoma may have contributed to the development of syringomyelia (14).

In conclusion, neurosurgeons should remember that a syringomyelia remote from the operation site could develop subsequent to surgical resection of an IDEM tuberculoma.

\section{REFERENCES}

1. Batzdorf U: Primary spinal syringomyelia: A personal perspective. Neurosurg Focus 15: E7, 2000

2. Belahsen MF, Maaroufi M, Messouak O, Sqalli N, TiznitS:Spinal tuberculous arachnoiditis with intradural extramedullary tuberculomas. J Neuroradiol 33: 140-143, 2006

3. Caplan LR, Norohna AB, Amico LL: Syringomyelia and arachnoiditis. J Neurol Neurosurg Psychiatry 53:106-113, 1990

4. Compton JS, Dorsch NW: 1984 Intradurally extramedullary tuberculoma of the cervical spine. J Neurosurg 60:200-203,1984

5. Dastur HM: Diagnosis and neurosurgical treatment of tuberculous disease of the CNS. Neurosurg Rev 6(3): $111-117,1983$
6. Ersoy Y, Ates O, Onal C, But AD, Cayli SR, Bayindir Y, Durmaz $\mathrm{R}$ : Cerebellar abscess and syringomyelia due to isoniasidresistant Mycobacterium tuberculosis. J Clin Neurosci 14: 86-89, 2007

7. Garg RK: Tuberculosis of the central nervous system. Postgrad Med J 75: 133-140,1999

8. Hui ACF, Chan YL, Kay R: Syrinx and tuberculoma formation in tuberculous arachnoiditis. Can J Neurol SCi 28:148-149, 2001

9. Kaynar MY, Kocer N, Gencosmanoglu BE, Hanci M: Syringomyelia- as a late complication of tuberculous meningitis. Acta Neurochirurgica 142:935-939, 2000

10. Kim MS, Kim KJ, Chung CK, Kim HJ: Intradural extramedullary tuberculoma of the spinal cord: A case report. J Korean Med Sci 15: 368-370, 2000

11. Luo L, Pino J: An intradural extramedullary tuberculoma of the spinal cord in a non-HIV-infected patient: Case Report and review of the literature lung 184: 187-193, 2006

12. Mathuriya SN, Khosla VK, Banerjee AK: Intradural extramedullary tuberculous spinal granulomas. Clin Neurol Neurosurg 90(2):155-158, 1988

13. Mirzai H: Tuberculoma of the cervical spinal canal mimicking en plaque meningioma. J Spinal Disord Tech 18(2):197-199, 2005

14. Muthukumar N, Sureshkumar V: Concurrent syringomyelia and intradural extramedullary tuberculoma as late complications of tuberculous meningitis. J Clin Neurosc 14: 1225-1230, 2007

15. Muthukumar N, Venkatachalam S, Ramesh VG: En plaque intradural extramedullary spinal tuberculoma and concurrent intracranial tuberculomas: Paradoxical response to antituberculous therapy. J Neurosurg Spine 6(2): 169-173, 2007

16. Roca B: Intradural extramedullary tuberculoma of the spinal cord: A review of reported cases. Journal of Infection 50, 425-431, 2005 